\title{
TGFA Gene
}

National Cancer Institute

\section{Source}

National Cancer Institute. IGFA Gene. NCI Thesaurus. Code C24855.

This gene is involved in angiogenesis and mitogenesis. 